\title{
СПРОМОЖНІСТЬ РЕФОРМОВАНОЇ СИСТЕМИ ОХОРОНИ ЗДОРОВ'Я М. КИЄВА ДО НАДАННЯ МЕДИЧНОЇ ДОПОМОГИ ХВОРИМ НА ЦЕРЕБРАЛЬНИЙ ІНСУЛЬТ
}

\author{
${ }^{1}$ Національний медичний університет імені О. О. Богомольця, м. Київ, Україна \\ ДВНЗ «Ужгородський національний університет», м. Ужгород, Україна
}

\begin{abstract}
Мета: дослідити рівень спроможності ресормованої системи охорони здоров'я м. Києва до надання медичної допомоги хворим на церебральний інсульт.

Матеріали і методи. При проведенні даного дослідження використано статистичний метод, метод структурнологічного аналізу та метод системного підходу. Матеріалами дослідження слугували дані галузевої статистичної звітності по м. Києву за 2014-2018 рр., укладені договори між закладами охорони здоров'я м. Києва та Національною службою охорони здоров'я України, починаючи 31 квітня 2020 р.

Результати. За умов впровадження системи державних фрінансових гарантій медичного обслуговування населення для надання медичної допомоги населенню з гострими мозковими інсультами заклади охорони здоров'я 31 квітня 2020 р. укладають договори з Національною службою охорони здоров'я України відповідно до пакетів медичних послуг за напрямами «Медична допомога при гострому мозковому інсульті» та «Медична реабілітація дорослих та дітей від трьох років з ураженням нервової системи», які включають специфрікацію надання та умови закупівлі медичних послуг. Дані пакети є недостатньо досконалими і потребують у майбутньому перегляду.

Для надання стаціонарної медичної допомоги при гострому мозковому інсульті система охорони здоров'я м. Києва має достатні госпітальні ресурси, але в більшості вони знаходяться в різних закладах охорони здоров'я, що створює перешкоди до надання якісної допомоги при різних формах інсультів та до недостатньо раціонального використання наявних ресурсів. При цьому тільки в двох закладах охорони здоров'я із десяти підрозділи візуалізації патологічного процесу працюють цілодобово, в тому числі у вихідні та святкові дні, а в решті закладів - у режимі роботи лікаря в денний час, що не дає можливості виконати умови договорів із Національною службою охорони здоров'я України, коли візуалізація процесу повинна здійснюватися протягом 60 хв перебування в лікарні.

Висновки. Отримані в ході дослідження результати вказують на недостатню спроможність реформованої системи охорони здоров'я в м. Києві забезпечити хворих на церебральні інсульти доступною та якісною медичною допомогою, в тому числі реабілітаційними послугами.
\end{abstract}

КЛЮЧОВІ СЛОВА: м. Київ; реформована система охорони здоров'я; церебральний інсульт; пацієнти; медична допомога; спроможність.

Церебральні інсульти є сучасною медико-демографічною та соціальною проблемою $[6,7]$. У провідних країнах Європи щорічно на церебральний інсульт хворіє до 0,2 \% населення, а в США мозковий крововилив щорічно реєструють у 37 000-52 400 жителів країни. Дані наукової літератури вказують на те, що тільки 38 \% осіб, які перенесли геморагічний інсульт, живуть після цього більше року $[1,5]$. В Україні теж спостерігають високий рівень захворюваності населення на церебральний інсульт [1].

За цих умов для збереження життя хворих важливе значення має надання їм своєчасної та ефективної медичної допомоги. Актуальність проблеми набуває значення за умов реформування системи охорони здоров'я [2] та впровадження норм Закону України «Про державні фрінансові гарантії медичного обслуговування населення» [4], яким визначено впровадження принципово нових механізмів фрінансування закладів охорони

(c) М. М. Прокопів, Г. О. Слабкий, А. Т. Яцина, 2020 здоров'я. 31 квітня 2020 р. розпочато другий етап реформи охорони здоров'я, в ході якого систему державних гарантій впроваджують при наданні спеціалізованої та високоспеціалізованої медичної допомоги. Розроблено та затверджено пакети медичних послуг [3]. При цьому специфікації та умови закупівлі пакетів медичних послуг у 2020 р. погоджені Міністерством охорони здоров'я 21 січня 2020 р. У тому числі затверджено пакет медичної допомоги при гострому мозковому інсульті.

Мета роботи: дослідити рівень спроможності рефрормованої системи охорони здоров'я м. Києва до надання медичної допомоги хворим на церебральний інсульт.

Матеріали і методи. При проведенні даного дослідження використано статистичний метод, метод структурно-логічного аналізу та метод системного підходу. Матеріалами дослідження слугували дані галузевої статистичної звітності по м. Києву за 2014-2018 рр., укладені договори між закладами охорони здоров'я м. Києва та 
Національною службою охорони здоров'я України, починаючи 31 квітня 2020 р.

Результати дослідження та їх обговорення. На початку дослідження проаналізовано специфрікацію надання та умови закупівлі медичних послуг за напрямом «Медична допомога при гострому мозковому інсульті». Аналіз специфрікації медичних послуг дозволив виявити як позитивні, так і негативні сторони даного документа. До позитивних сторін документа віднесено вимоги щодо проведення нейровізуалізації всім пацієнтам із підозрою на гострий мозковий інсульт (протягом 60 хв із моменту звернення пацієнта в заклад та анестезіологічний супровід пацієнта для проведення нейровізуалізації); проведення системної тромболітичної терапії (при ішемічному інсульті), включаючи забезпечення необхідних лікарських засобів; моніторинг клінічних, біохімічних показників, рівня електролітів, лабораторних показників системи гемостазу, ЕКГ; забезпечення знеболювання та медикаментозної терапії; проведення та документування скринінгу щодо порушень ковтання у всіх пацієнтів до початку годування чи приймання ліків через рот (не пізніше 24 год після госпіталізації) з забороною годування чи приймання ліків через рот у разі ознак дисфрагії; забезпечення консультації логопеда (терапевта мови та мовлення) у перші 48 год після госпіталізації; проведення заходів із вторинної профрілактики захворювання; надання послуг з медичної реабілітації в гострий період та переведення пацієнтів до відділення (центру) реабілітації для надання послуг із медичної реабілітації у підгострий/відновний період; розроблення та організація окремого заняття для родини/доглядачів. Негативними сторонами доку- мента $є$ вимоги щодо застосування ендоваскулярних методів лікування та забезпечення нейрохірургічної допомоги у разі наявності відповідного обладнання у закладі. Ця норма документа завідомо передбачає можливість надання неадекватної медичної допомоги при геморагічному інсульті та не стимулює створення комплексних медичних центрів медичної допомоги при церебральних інсультах. При цьому умови закупівлі медичних послуг за напрямом «Медична допомога при гострому мозковому інсульті» теж не передбачають наявності обов'язкових умов надання, навіть за потреби, нейрохірургічної допомоги. Необхідно відзначити, що недоліком пакета $€$ єдиний тариф оплати при ішемічному і геморагічному інсультах, які вимагають різних підходів до лікування і суттєво різних витрат та ресурсної бази при цьому.

Що стосується медичної реабілітації у підгострий/відновний період гострого церебрального інсульту, то для надання населенню вказаних послуг розроблено та затверджено пакет медичних послуг за напрямом «Медична реабілітація дорослих та дітей від трьох років з ураженням нервової системи», який включає і надання медичних реабілітаційних послуг особам, які перенесли гострий мозковий інсульт.

Далі була прорахована прогнозна кількість хворих, які підлягають стаціонарному лікуванню за пакетом «Медична допомога при гострому мозковому інсульті в стаціонарних умовах». Розрахунок проводили на основі показників захворюваності населення м. Києва на церебральні інсульти і транзиторні церебральні ішемічні напади та споріднені синдроми за період 20142018 рр. (табл. 1).

Таблиця 1. Кількість хворих та прогнозні дані захворюваності на церебральні інсульти і транзиторні церебральні ішемічні напади та споріднені синдроми за період 2014-2018 рр.

\begin{tabular}{|l|c|c|c|c|c|c|c|}
\hline \multicolumn{1}{|c|}{ Нозологічні фрорми } & 2014 & 2015 & 2016 & 2017 & 2018 & $\begin{array}{c}\text { Середній } \\
\text { показник за рік }\end{array}$ & $\begin{array}{c}\text { Прогнозна } \\
\text { кількість } \\
\text { на 9 місяців }\end{array}$ \\
\hline Церебральні інсульти & 4883 & 5254 & 5102 & 4753 & 3373 & 4673 & 3705 \\
\hline $\begin{array}{l}\text { Транзиторні церебральні } \\
\text { ішемічні напади }\end{array}$ & 737 & 660 & 770 & 782 & 629 & 716 & 537 \\
\hline Всього & 5620 & 5914 & 5872 & 5535 & 4002 & 5389 & 4242 \\
\hline
\end{tabular}

Проведені розрахунки на основі показників захворюваності населення м. Києва на гострі порушення мозкового кровообігу показали, що згідно 3 прогнозом в столиці за 9 місяців 2020 р. може потребувати стаціонарної медичної допомоги 4242 особи.

Далі нами вивчено питання щодо укладання закладами охорони здоров'я міста договорів із Національною службою охорони здоров'я України із надання медичної допомоги при церебральних інсультах та їх ресурси. Вивчали також питання наявності в закладах охорони здоров'я (303) госпітальних ліжок неврологічного та нейрохірургічного профрілів, режиму роботи служби візуалізації патологічного процесу, кількості хворих, які підлягають лікуванню в кожній лікарні, прогнозній кількості днів їх стаціонарного лікування та можливості лікарні їх забезпечити. При розрахунках використано такі дані: середнє перебування хворого з мозковим інсультом на госпітальному ліжку становить 16,1 дня, а середня кількість роботи госпітального ліжка за 9 місяців - 
260 днів. Отримані в ході дослідження дані наведено в таблиці 2.

Отримані в ході дослідження та наведені в таблиці 2 дані вказують на те, що 303 укладені договори для надання стаціонарної медичної допомоги 4361 хворим на гострі мозкові інсульти при прогнозній потребі 4242. Для надання стаціонарної медичної допомоги хворим на мозкові інсульти в місті фрункціонує 930 неврологічних та 205 нейрохірургічних госпітальних ліжок. На даних ліжках надають не тільки стаціонарну допомогу вказаним хворим, а й хворим з іншими захворюваннями даного профрілю. Необхідно зазначити, що тільки у двох лікарнях (міська клінічна лікарня (МКЛ) № 1 та Олександрівська клінічна лікарня) розгорнуті госпітальні ліжка неврологічного та нейрохірургічного профрілів. У клінічній лікарні швидкої медичної допомоги (ЛШМД) розгорнуті тільки ліжка нейрохірургічного профрілю. Такий поділ госпітальних ліжок за лікарнями і відсутність «інсультних центрів» призводить до того, що на даних ліжках отримують лікування непрофрільні пацієнти та викликає необхідність перевезення їх із лікарні в лікарню. Це, в свою чергу, затримує час початку адекватного лікування.

Проблемою $€$ наявність тільки в двох лікарнях (ЛшМД та Олександрівська клінічна лікарня) цілодобової, в тому числі у вихідні та святкові дні, можливості візуалізації патологічного процесу. В решті лікарень служби візуалізації патологічного процесу працюють в режимі роботи лікаря в денний час. Це знижує якість медичної допомоги, оскільки світовим стандартом медичної допомоги $€$ візуалізація патологічного процесу в терміні чотирьох годин від початку захворювання, що забезпечує визначення лікувальної тактики, яка відрізняється при ішемічному і геморагічному інсультах.

Обов'язковим етапом надання медичної допомоги при мозковому інсульті є реабілітація, яку проводять як у стаціонарних, так і амбулаторних умовах. У місті функціонує 200 госпітальних ліжок для надання нейрореабілітаційної допомоги дорослому населенню. Дані про них у розрізі 303 міста представлено на рисунку 1.

Національною службою охорони здоров'я України укладено договори з метою фрінансування медичної допомоги за пакетом медичних послуг «Медична реабілітація дорослих та дітей від трьох років з ураженням нервової системи» 3 такими 3О3: МКЛ № 1, 7, 8 та КНП «Київський міський клінічний госпіталь ветеранів війни», що $є$ недостатнім для забезпечення осіб, які перенесли гостре порушення мозкового кровообігу, реабілітаційними послугами.

Таблиця 2. Заклади охорони здоров'я м. Києва, які уклали договори з Національною службою охорони здоров'я України із надання медичної допомоги при церебральних інсультах та їх ресурси, 2020 p.

\begin{tabular}{|c|c|c|c|c|c|c|}
\hline \multirow{2}{*}{ Заклад } & \multirow{2}{*}{$\begin{array}{c}\text { Договірна } \\
\text { кількість } \\
\text { хворих }\end{array}$} & \multirow{2}{*}{\begin{tabular}{|c|} 
Прогнозна \\
кількість днів \\
стаціонарного \\
лікування
\end{tabular}} & \multicolumn{2}{|c|}{ Кількість ліжок } & \multirow{2}{*}{$\begin{array}{c}\text { Режим роботи } \\
\text { служби візуалізації } \\
\text { патологічного } \\
\text { процесу }\end{array}$} & \multirow{2}{*}{$\begin{array}{c}\text { Кількість ліжко } \\
\text { днів забезпечує } \\
\text { наявна кількість } \\
\text { госпітальних ліжок }\end{array}$} \\
\hline & & & $\begin{array}{l}\text { невро- } \\
\text { логічних }\end{array}$ & $\begin{array}{l}\text { нейрохірур- } \\
\text { гічних }\end{array}$ & & \\
\hline $\begin{array}{l}\text { Міська клінічна } \\
\text { лікарня № } 1 \\
\end{array}$ & 604 & 9724,4 & 120 & 20 & $\begin{array}{l}\text { У режимі роботи } \\
\text { лікаря в денний час }\end{array}$ & 36400 \\
\hline $\begin{array}{l}\text { Міська клінічна } \\
\text { лікарня № } 3\end{array}$ & 638 & 10271,8 & 165 & - & $\begin{array}{l}\text { У режимі роботи } \\
\text { лікаря в денний час }\end{array}$ & 42900 \\
\hline $\begin{array}{l}\text { Міська клінічна } \\
\text { лікарня № } 4\end{array}$ & 537 & 8645,7 & 160 & - & $\begin{array}{l}\text { У режимі роботи } \\
\text { лікаря в денний час }\end{array}$ & 41600 \\
\hline $\begin{array}{l}\text { Міська клінічна } \\
\text { лікарня № } 6\end{array}$ & 488 & 7856,8 & 50 & - & $\begin{array}{l}\text { У дні чергування } \\
\text { лікарні }\end{array}$ & 13000 \\
\hline $\begin{array}{l}\text { Міська клінічна } \\
\text { лікарня № } 7\end{array}$ & 272 & 4379,2 & 80 & - & $\begin{array}{l}\text { У режимі роботи } \\
\text { лікаря в денний час }\end{array}$ & 20800 \\
\hline $\begin{array}{l}\text { Міська клінічна } \\
\text { лікарня № } 8\end{array}$ & 306 & 4926,6 & 155 & - & $\begin{array}{l}\text { У режимі роботи } \\
\text { лікаря в денний час }\end{array}$ & 40300 \\
\hline $\begin{array}{l}\text { Міська клінічна } \\
\text { лікарня № } 9\end{array}$ & 117 & 1883,7 & 70 & - & $\begin{array}{l}\text { У режимі роботи } \\
\text { лікаря в денний час }\end{array}$ & 18200 \\
\hline $\begin{array}{l}\text { Міська клінічна } \\
\text { лікарня № } 15\end{array}$ & 293 & 4717,3 & 50 & - & $\begin{array}{l}\text { У режимі роботи } \\
\text { лікаря в денний час }\end{array}$ & 13000 \\
\hline ЛШМД & 325 & 5232,5 & - & 135 & $\begin{array}{l}\text { Цілодобово, в тому } \\
\text { числі у вихідні та } \\
\text { святкові дні }\end{array}$ & 35100 \\
\hline $\begin{array}{l}\text { Олександрівська } \\
\text { клінічна лікарня }\end{array}$ & 781 & 12574,1 & 80 & 50 & $\begin{array}{l}\text { Цілодобово, в тому } \\
\text { числі у вихідні та } \\
\text { святкові дні }\end{array}$ & 33800 \\
\hline Всього & 4361 & 70212,1 & 930 & 205 & & 295100 \\
\hline
\end{tabular}




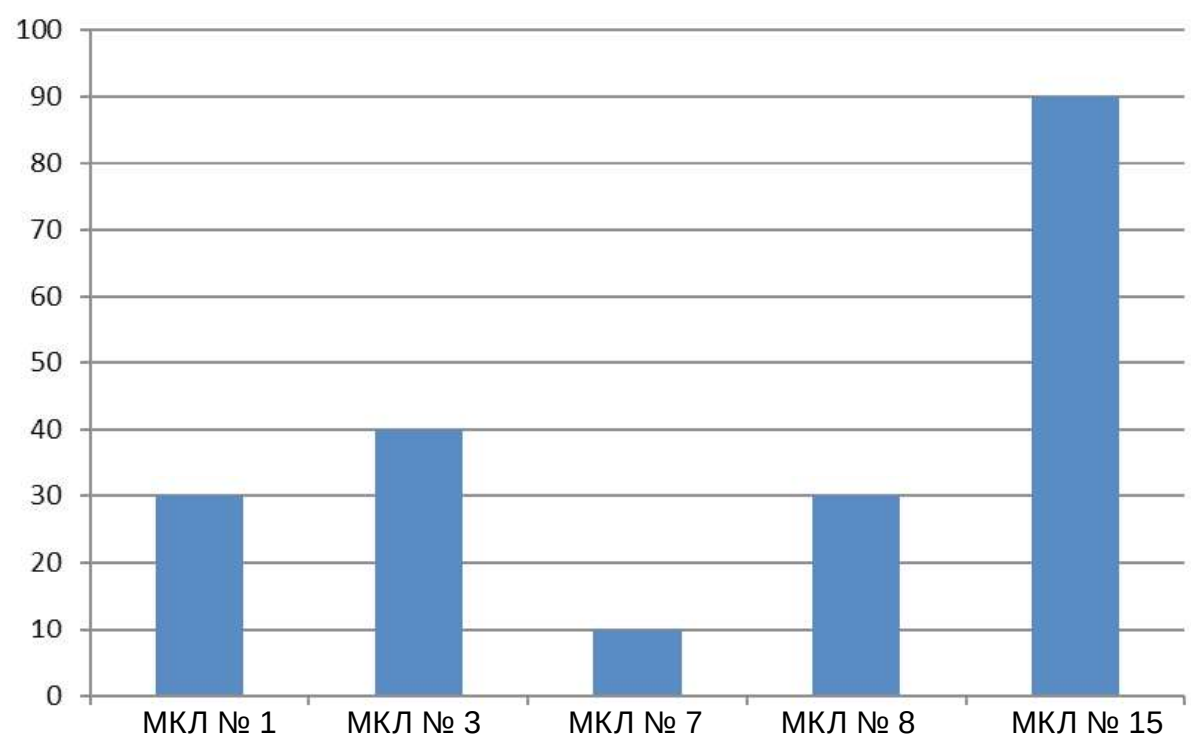

Puc. 1. Ліжковий фонд 303 із надання нейрореабілітаційної допомоги особам, які перенесли гостре порушення мозкового кровообігу.

\section{Висновки}

За умов впровадження системи державних фрінансових гарантій медичного обслуговування населення для надання медичної допомоги населенню 3 гострими мозковими інсультами заклади охорони здоров'я 31 квітня 2020 р. укладають договори з Національною службою охорони здоров'я України відповідно до пакетів медичних послуг за напрямами «Медична допомога при гострому мозковому інсульті» та «Медична реабілітація дорослих та дітей від трьох років з ураженням нервової системи», які включають специфрікацію надання та умови закупівлі медичних послуг. Дані пакети $€$ недостатньо досконалими і потребують у майбутньому перегляду.

Для надання стаціонарної медичної допомоги при гострому мозковому інсульті система охорони здоров'я м. Києва має достатні госпітальні ресурси, які полягають в достатній кількості неврологічних та нейрохірургічних госпітальних ліжок, але в більшості вони знаходяться в різних закладах охорони здоров'я, що створює пере- шкоди до надання якісної допомоги при різних формах інсультів та недостатньо раціональне використання наявних ресурсів. При цьому тільки в двох закладах охорони здоров'я із десяти підрозділи візуалізації патологічного процесу працюють цілодобово, в тому числі у вихідні та святкові дні, а в решті закладів - у режимі роботи лікаря в денний час, що не дає можливість виконати умови договорів з Національною службою охорони здоров'я України, коли візуалізація процесу повинна здійснюватися протягом 60 хв перебування в лікарні.

Наявні ресурси системи охорони здоров'я м. Києва не в змозі забезпечити всіх осіб, які перенесли гострий мозковий інсульт, реабілітаційними послугами.

Перспективи подальших досліджень пов'язані $з$ вивченням якості та ефективності надання медичної допомоги населенню м. Києва в ресрормованій системі охорони здоров'я при мозкових інсультах.

\section{Список літератури}

1. Віничук С. М. Гострий ішемічний інсульт / С. М. Віничук, М. М. Прокопів. - К. : Наукова думка, $2006 .-286$ с.

2. Національна стратегія ресрормування системи охорони здоров'я в Україні на період 2015-2020 років [Електронний ресурс] / Стратегічна дорадча група з питань реформування системи охорони здоров'я в Україні, 2015. Режим доступу : http://healthsag.org.ua/strategiya/. - Назва з екрана.

3. Пакети медичних послуг. Зміст та підхід до контрактування закладів охорони здоров'я / Національна служба здоров'я України. - К., 2020. - 59 с.

4. Про державні фрінансові гарантії медичного обслуговування населення: Закон України від 19 жовтня 2017 року № 2168-VIII [Електронний ресурс] - Режим доступу : https://zakon.rada.gov.ua/laws/show/2168-19\#Text. - Haзва 3 екрана.

5. Фартушна О. Є. Транзиторні ішемічні атаки / О. Є. Фартушна, С. М. Віничук. - К. : «Авіцена», $2014 .-216$ с.

6. Fartushna O. Ye. Brain injury in patients with acute TIA: clinical features in different TIA subtypes / O. Ye. Fartushna, S. M. Vinychuk // International Neurological Journal. - 2017. - No. 3 (89). - P. 13-18.

7. World Stroke Organization. Global Stroke Fact Sheet. 26.02.2019. Access mode : https://www.world-stroke.org/images/ WSO_Global_Stroke_Fact_Sheet_final.pdf 


\section{References}

1. Vinychuk, S.M., \& Prokopiv, M.M. (2006). Hostryi ishemichnyi insult [Acute ischemic stroke]. Kyiv: Naukova dumka [in Ukrainian].

2. (2015). Natsionalna stratehiia reformuvannia systemy okhorony zdorovia v Ukraini na period 2015-2020 rokiv [National strategy for health care reform in Ukraine for the period 2015-2020]. Stratehichna doradcha hrupa z pytan reformuvannia systemy okhorony zdorovia v Ukraini - Strategic advisory group on health care reform in Ukraine. Retrieved from: http://healthsag.org.ua/strategiya/ [in Ukrainian].

3. (2020). Pakety medychnykh posluh. Zmist ta pidkhid do kontraktuvannia zakladiv okhorony zdorovia. Natsionalna sluzhba zdorovia Ukrainy [Packages of medical services. Content and approach to contracting health care facilities. National Health Service of Ukraine]. Kyiv [in Ukrainian].

4. (2017). Zakon Ukrainy „Pro derzhavni finansovi harantii medychnoho obsluhovuvannia naselennia” 19 zhovtnia 2017 roku No. 2168-VIII [Law of Ukraine "On State Financial Guarantees of Medical Care of the Population" October 19, 2017 No. 2168-VIII]. Retrieved from: http://search.ligazakon.ua/l_doc2.nsf/link1/T172168.html [in Ukrainian]. 5. Fartushna, O.Ye., \& Vinychuk, S.M. (2014). Tranzytorni ishemichni ataky [Transient ischemic attacks]. Kyiv: $\mathrm{PH}$ "Avitsena" [in Ukrainian].

6. Fartushna, O.Ye., \& Vinychuk, S.M. (2017). Brain injury in patients with acute TIA: clinical features in different TIA subtypes. International Neurological Journal., 3 (89), 13-18.

7. (2019). World Stroke Organization. Global Stroke Fact Sheet. Retrieved from: https://www.world-stroke.org/ images/WSO_Global_Stroke_Fact_Sheet_final.pdf

\section{CAPACITY OF THE REFORMED HEALTH CARE SYSTEM OF KYIV CITY TO PROVIDE MEDICAL CARE TO PATIENTS WITH CEREBRAL STROKE}

M. M. Prokopiv ${ }^{1}$, G. O. Slabkiy², A. T. Yatsina ${ }^{2}$

${ }^{1}$ O. Bohomolets National Medical University, Kyiv, Ukraine

${ }^{2}$ Uzhhorod National University, Uzhhorod, Ukraine

Purpose: to study the capacity level of the reformed health care system in Kyiv city to provide medical care to patients with cerebral stroke.

Materials and Methods. The statistical method, the method of structural and logical analysis, and the method of systemic approach were applied in the course of study. The data of sectoral statistical reports in Kyiv for the years 2014-2018, the concluded contracts between the health care institutions of Kyiv and the National Health Care Service of Ukraine since April 1, 2020 were used as materials for the study.

Results. In the frames of implementation of the System of State financial guarantees of medical care for medical aid to the population with acute cerebral strokes health care establishments from April 1, 2020 conclude contracts with the National Health Service of Ukraine according to the packages of medical services in the directions "Medical care for acute cerebral stroke" and "Medical rehabilitation of adults and children from three years of age with nervous system lesions" which include the specification of provision and conditions for procurement of medical services. These packages are not perfect and need the revision in future.

In order to provide inpatient care for patients with acute cerebral stroke, the health care system of Kyiv has sufficient hospital resources, but in their majority they are located in different health care establishments, which creates obstacles to provide qualified care in different forms of strokes and to insufficiently rational use of available resources. At the same time only in 2 health care establishments from ten departments of pathological process visualization work round-the-clock including the weekends and holidays, and in the rest of establishments - in the mode of doctor's work at daytime, that does not allow to fulfill the terms of contracts with National Health Care Service of Ukraine, when visualization process should be carried out within 60 minutes of patient's stay in a hospital.

Conclusions. The results obtained in the course of study indicate the insufficient capacity of the reformed health care system in Kyiv to provide patients with cerebral strokes with accessible and qualified medical care with rehabilitation services.

KEY WORDS: Kyiv; reformed health care system; cerebral stroke; patients; medical care; capacity.

Рукопис надійшов до редакції 22.05.2020 р.

Відомості про авторів:

Прокопів Марія Мирославівна - кандидат медичних наук, доцент кафедри неврології Національного медичного університету імені О. О. Богомольця.

Слабкий Геннадій Олексійович - доктор медичних наук, професор, завідувач кафедри наук про здоров'я ДВНЗ «Ужгородський національний університет»; тел.: +38(050) 171-16-48.

Яцина Андреа Тіборівна - кандидат медичних наук, асистент кафедри наук про здоров'я

ДВНЗ «Ужгородський національний університет». 